\title{
Gamification in History Learning: A Literature Review
}

\author{
Oka Agus Kurniawan Shavab ${ }^{1,5^{*}}$, Leli Yulifar ${ }^{2}$, Nana Supriatna ${ }^{3}$, Agus Mulyana ${ }^{4}$ \\ 1, 2, 3,4 Universitas Pendidikan Indonesia \\ ${ }^{5}$ Universitas Siliwangi \\ *Corresponding author. Email: okaaks@unsil.ac.id
}

\begin{abstract}
This paper aims to describe the use of gamification in history learning. Gamification is the use of games and their elements in classroom learning activities. The implementation of gamification requires a platform that teachers and students can access. The platform can use an existing platform or create your own. Gamification is needed as a way to solve problems found in the classroom. The research method used in this paper is a literature review, which is research that critically examines the knowledge, ideas, or findings contained in academic-oriented literature and formulates theoretical and methodological contributions to specific topics. Gamification literature has been widely used in contributing to learning activities, including history learning. Several studies have attempted to explain how the use of gamification in historical learning activities and measure the effect of the use of gamification in history learning. As research findings, we identified several effects of using gamification in historical education, including the learning process, gamification components, teacher perceptions, interests, understanding material, student involvement in learning, motivation and interests, and student perceptions.
\end{abstract}

Keywords: Gamification, History Learning, Literature Study, History Learning Innovation.

\section{INTRODUCTION}

Ideal learning not only creates interactions between teachers or lecturers and their students, but students are also able to interact with learning sources, such as various reading materials, resource persons, natural environment, socio-culture, and others [1]. Another thing is that students can analyze the material presented and provide answers to existing problems and analyze the material received to be actualized in themselves to answer the issues they face at this time. Based on this, lecturers or teachers should be able to develop learning activities and create an ideal learning environment to equip and increase the potential of their students.

In creating the right learning environment, lecturers or teachers must be able to create and choose suitable teaching materials, methods, or learning models to support the potential of their students. Many ways can be done by adjusting students' character today, for example, the use of games and their elements in learning history in the classroom. The essence of using games in learning is a fun atmosphere. All learning methods must create an atmosphere of joy in learning or joyful learning [2]. Conditions like this should be able to be utilized by applying gamification to education.

Gamification is the use of game elements in non-game activities [3],[4]. Gamification in education refers to introducing game design elements and gameful experiences in the design of learning processes [5], [6]. Gamification is an attempt to apply game elements to the classroom to engage and motivate students [7], [8]. Another thing is explained that gamification is using game-based mechanics, aesthetics, and game thinking to engage people, motivate action, promote learning, and solve problems [9]. Gamification comes in many forms, and the most widely used are points, leaderboards, and medals [10]. The other elements are users, tasks, levels/stage, and progress bar.

In its implementation, teachers or lecturers can choose various existing platforms, and students can take tests or quizzes and submit assignments while receiving direct feedback [11]. Media that can be used in the implementation of gamification include Kahoot !, socrative, dojo class, badges class, craft class, ribbon hero, play brighter, goose chase, Minecraft: education edition, and others [12]. Using this application, students will get direct feedback on their assignments with true and false information [13]. Students with a high level of confidence will participate more in learning, which impacts the abilities they will build to acquire the necessary skills [14].

The use of gamification in classroom learning activities has been widely practiced, including in history learning activities. Gamification is carried out as a form of creativity for history teachers in teaching and a solution to problems found in the classroom. This study still needs to be developed to become a reference for teachers/lecturers/researchers interested in this field.

This paper aims to systematically review the literature and provide a description of the contribution of gamification to historical learning activities. This study offers several findings and research insights as benefits that can be taken. As for experiential research, we found that motivation, the learning process to be effective and attractive, student involvement, student motivation, and 
interest have emerged as the most relevant constructs with a reliable scale and consistent theory.

\section{METHOD}

The research method used is a literature review, a study that critically examines the knowledge, ideas, or findings in the theoretical and methodological literature on a particular topic. The focus of this research is to find various theories or pictures that are used to analyze and answer the study questions formulated. A literature review is an excellent way of synthesizing research findings to show evidence on a meta-level and uncover areas where more research is needed, which is a critical component of creating theoretical frameworks and building conceptual models [15]. A literature review can also be described as a more or less systematic way to collect and synthesize previous research [16], [17]. The criteria used in conducting a literature review are: choose a review theme, determine the appropriate article, carry out analysis and synthesis of literature, and review writing organization [18].

\section{FINDING AND DISCUSSION}

The successful use of digital games and gamification research in historical learning has been shown, including the following:

\section{Learning Process}

Digital games can foster a practical and attractive learning process, especially among students. The Digital Game-Based Learning (DGBL) approach utilizes games as a medium for delivering learning content. The gamification model that is carried out in influencing the learning process is by combining Instructional Design (ID) and the game development process, which is named DGBL-ID. The model consists of five stages, namely analysis, design, development, implementation, evaluation. This model uses the virtools platform in its application, and the main components consist of pedagogy and digital games. For the pedagogy component, the elements are as follows: setting learning objectives, setting learning theory, educational psychology, the need for the state curriculum, patriotism, and moral values, and the theory of memorization and forgetfulness. Meanwhile, for digital games, the elements are as follows: game story background, rules, immersive, enjoyment, feedback, multimedia technology, challenge $\&$ competition, and reward [19].

\section{Gamification Components}

Thirteen components can be used in developing and designing gamification in historical learning, namely: learning activities, game attributes, learning content, learning outcomes, user interfaces, game mechanisms, state curriculum needs, reflection, challenges, rewards, immersive, narrative, and dynamics of the game [20].

\section{Perception Teacher}

Teachers perceive the use of exams with better gamification than traditional examinations. Some conclusions that can be drawn are as follows: 1). The use of gamification can motivate students and can be done outside the classroom, satisfaction in carrying out easy exams, 2). Fostering student interest in learning, creating pleasure in education, and the desire to continue playing games because of the desire to compete, and 3) the test model using gamification is very suitable for learning activities [21].

\section{Interests and Motivation}

The form of gamification is by applying a computer game with the history of Ken Arok and Ken Dedes from the Singhasari Kingdom. It is empirically proven that gamification can increase students' interest and motivation and help them overcome their difficulties in taking history lessons. The use of gamification makes it easier for students to remember historical figures and events [22].

\section{Understand the material}

Gamification can influence students in understanding historical material. Game designs must be prepared, including Title Pages, Story and Gameplay, Game Flow, Characters and Controls, Main Gameplay Concepts and Platform-Specific Features, Game World Interfaces, Mechanics and Power-ups, Enemies and Bosses, Cutscenes, Bonuses Materials, and Comps. The determination of gamification elements uses the GaML (Gamification Modeling Language) method. This method determines the need for gamification in two aspects, namely game interface patterns and game design patterns [23]. Gamification techniques can also convey a lot of historical information that is more accurate. In addition, it can offer various materials that you want to learn, can be done anytime and anywhere; the last is independence in learning because the instructions are clear [24]. Not only that, gamification supports a deeper understanding of the historical objects it studies [25].

\section{Student Involvement}

Gamification can influence student involvement in class. This can be seen from the ability to hear during learning activities with feedback given an ability to listen to the badge. Another involvement is being able to control emotions by giving points if students manage to control them and if students can solve problems by working together. The application that can be used is classcraft [26].

Another thing that can be seen is that gamification can influence students on a unique model of involvement to think about the present and the past, observe historical records, engage in historical simulations, and repeat material historical events [27]. Another form of gamification that uses role-playing games offers students 
the opportunity to solve complex problems and texts, carry out gamification activities directly in class, and build creativity in learning [28]

\section{Motivation and Interests}

Game-based learning and gamification enables educational innovation processes and increases student motivation and interest. In addition, reason must also be combined with content and a pedagogical approach to allow better integration in schools. Another thing is that gamification can develop creativity, collaboration, skills and facilitate active learning, participation, interest, and student enjoyment [29].

Another thing also states that the use of gamification of ancient kingdoms in the archipelago affects student interest in learning. This platform is suitable for use as a learning medium to study the Hindu-Buddhist kingdom in Indonesia [30]. It is also based on experience that the learning approach with gamification creates a more effective and exciting learning process by involving students in the learning process. Not only that, but students' interest in learning also increases because they learn while playing [31]. It is the same as the previous opinion that gamification can affect student interest in learning activities and can also help increase student commitment and motivation which can be done by taking advantage of students' habits in playing games [32]. This is also supported by the statement that there is a synergy in using video games in learning activities and has become the basis for research [33],[34].

\section{Students' perceptions}

Students' perceptions in using gamification are excellent because students are first informed about the workings of the platform that will be used through learning videos. Students involve themselves in the learning process by watching videos. During the implementation of gamification, students collaborate with their friends, which affects the learning situation and motivation. Activities in the classroom are based on case studies, simulations, material analysis, cooperation, etc., which are combined with maximizing gamification elements, such as points and awards. After learning activities, students are given information regarding their progress during gamification activities to motivate them to excel [35]. Gamification techniques are also a valuable tool that can reach many people, especially young people or pioneers, using digital applications [36].

\section{CONCLUSION}

This study provides a literature review based on the use of gamification in historical learning. Experiencebased empirical and literature shows that gamification in history learning affects students in several ways, including motivation, interests, the learning process, interactions in learning, and understanding of the material. Gamification also gets good perceptions from teachers and students after being in history learning activities. Equipment is also a gamification component offered in history learning. These results can be used as a reference in historical learning research that utilizes gamification.

\section{ACKNOWLEDGMENTS}

The author would like to thank those who contributed to completing this paper and also to the participants for their comments and suggestions while participating in The 6th International Conference on Education \& Social Sciences (the 6th ICESS), Semarang April, 09-10 2021

\section{REFERENCES}

[1] Widja, I. G. (2018). Pembelajaran Sejarah Yang Mencerdaskan Suatu Alternatif Menghadapi Tantangan dan Tuntutan Jaman yang Berubah. Jurnal Pendidikan Sejarah Indonesia, 1(2), 117134. https://doi.org/10.17977/um033v1i22018p1 17

[2] Supriatna, N., \& Maulidah, N. (2020). Pedagogi Kreatif: Menumbuhkan Kreativitas dalam Pembelajaran Sejarah dan IPS. PT Remaja Rosdakarya.

[3] Deterding, S., O’Hara, K., Sicart, M., Dixon, D., \& Nacke, L. (2011). Gamification: Using game design elements in non-gaming contexts. Conference on Human Factors in Computing Systems - Proceedings, January, 2425-2428. https://doi.org/10.1145/1979742.1979575

[4] Fulton, J. N. (2019). Theory of Gamification-Motivation. Online Submission. https://eric.ed.gov/?id=ED607091

[5] Caponetto, I., Earp, J., \& Ott, M. (2014). Gamification and education: A literature review. Proceedings of the European Conference on Games-Based Learning, 1(October), 50-57.

[6] Dichev, C., \& Dicheva, D. (2017). Gamifying education: what is known, what is believed and what remains uncertain: a critical review. In International Journal of Educational Technology in Higher Education (Vol. 14, Issue 1). International Journal of Educational Technology in Higher Education. https://doi.org/10.1186/s41239-017-0042-5

[7] Cheong, C., Filippou, J. \& Cheong, F. (2014). Towards the gamification of learning: Investigating student perceptions of game elements. Journal of Information Systems Education, 25(3), pp. 233-244.

[8] Seaborn, K., \& Fels, D. I. (2015). Gamification in 
theory and action: A survey. International Journal of Human Computer Studies, 74, 14-31. https://doi.org/10.1016/j.ijhcs.2014.09.006

[9] Kapp, K. M. (2012) The Gamification of Learning and Instruction: Case-Based Methods and Strategies for Training and Education. An Imprint of John Wiley \& Sons, United States of America.

[10] Hanus, M.D., \& Fox, J. (2015). Assessing the effects of gamification in the classroom: A longitudinal study on intrinsic motivation, social comparison, satisfaction, effort, and academic performance. Comput. Educ., 80, 152-161.

[11] Faiella, F., \& Ricciardi, M. (2015). Gamification and learning: A review of issues and research. Journal of E-Learning and Knowledge Society, 11(3), 13-21. https://doi.org/10.20368/1971$\underline{8829 / 1072}$

[12] Shavab, O. A. K. (2018). Gamification In History Learning As An Effort To Answer The Challenges In Facing Industrial Revolution 4.0. The 3 rd International Seminar on Social Studies and History Education (ISSSHE), 3, 371-376.

[13] Lynch, M. (2017). 8 Must Have Gamification Apps, Tools, and Resources. https://www.thetechedvocate.org/8-mustgamification-apps-tools-resources/.

[14] Schunk, D. H., \& DiBenedetto, M. K. (2016). Handbook of Motivation at School. In D. B. M. Kathryn R. Wentzel (Ed.).

[15] Snyder, H. (2019). Literature review as a research methodology: An overview and guidelines. Journal of Business Research, 104(March), 333339.

https://doi.org/10.1016/j.jbusres.2019.07.039

[16] Baumeister, R. F., \& Leary, M. R. (1997). Writing narrative literature reviews. Review of General Psychology, 1(3), 311-320. https://doi.org/10.1037/1089-2680.1.3.311

[17] Tranfield, D., Denyer, D., \& Smart, P. (2003). Towards a Methodology for Developing Evidence-Informed Management Knowledge by Means of Systematic Review* Introduction: the need for an evidence- informed approach. British Journal of Management, 14, 207-222. https://doi.org/10.1111/1467-8551.00375

[18] Rhamdani, A., Rhamdani, M. A., \& Amin, A. S. (2014). Writing a Literature Review Research Paper: A step-by-step approach. International Journal of Basic and Applied Science, 3 (1), 47 56.

[19] Zin, N. A. M., Jaafar, A., \& Yue, W. S. (2009). Digital game-based learning (DGBL) model and development methodology for teaching history. WSEAS Transactions on Computers, 8(2), 322333.

[20] Ghulamani, S., Shah, A., \& Khowaja, K. (2020). Review of Components from Frameworks and Models for DGBL for History Based Courses. 4(1), 9-16.

[21] Colomo-Magaña, E., Sánchez-Rivas, E., RuizPalmero, J., \& Sánchez-Rodríguez, J. (2020). Percepción docente sobre la gamificación de la evaluación en la asignatura de Historia en educación secundaria. Información Tecnológica, 31(4), 233-242. https://doi.org/10.4067/s071807642020000400233

[22] Chowanda, A., \& Chowanda, A. D. (2016). Gamification of Learning: Can Games Motivate Me to Learn History? ComTech: Computer, Mathematics and Engineering Applications, 7(3), 225-232.

https://doi.org/10.21512/comtech.v7i3.2503

[23] Wijaya, A. B., Suyanto, \& Sukoco. (2017). Gamification Pelajaran Sejarah Perjuangan Kemerdekaan Menggunakan Metode Scot. Jurnal Telematika, 10 (1),23-35.

[24] Karner, F.W. \& Härtel, G. (2010). Theory and Taxonomies of Serious Games; ENTRExplorer.

[25] Stocks, C., Birley, B., And Collins, R. (2018). Stories from the Frontier: Linking Past and Present at Vindolanda through Digital Gameplay. Thersites. 8, 97-109.

[26] Janiec, J. (2015). Use of Gamification in the IB History Class and as a Tool for Form Teacher. New Empirical Research and Solutions. KulturaSpołeczeństwo-Edukacja, $\quad 7(1), \quad 105$. https://doi.org/10.14746/kse.2015.1.7

[27] Metzger, S. A., \& Paxton, R. J. (2016). Gaming History: A Framework for What Video Games Teach About the Past. Theory and Research in Social Education, 44(4), 532-564. https://doi.org/10.1080/00933104.2016.1208596

[28] Fehleison, J. 1. (2019). Reacting to the Past and Role-Playing Games in Early Modern History.The sixteenth century journal, 50(4), 1142-1148.

[29] Cózar-Gutiérrez, R., \& Sáez-López, J. M. (2016). Game-based learning and gamification in initial teacher training in the social sciences: an experiment with MinecraftEdu. International Journal of Educational Technology in Higher Education, 13(1). https://doi.org/10.1186/s41239016-0003-4

[30] Arifin, Y., Martín, M., Ryan, R., \& Dratama, R. (2018). Gamification for the Ancient Kingdom of 
Nusantara with User-Centered Design Approach. ComTech, 9(1), 9-14.

[31] Dimova, M., Paneva-Marinova, D., \& Pavlova, L. (2018). Towards better understanding of ancient civilizations by storytelling and gaming. TEM Journal, $\quad 7(3)$, 658-661. https://doi.org/10.18421/TEM73-24.

[32] Mariotti, S., \& Marotta, N. (2020). Gioco e storydoing: strumenti didattici per 1 , insegnamento della storia nella scuola primaria. Journal of Research and Didactics of History, 2 (1).

[33] Gee, J. P. (2008). Learning and Games. The Ecology of Games: Connecting Youth, Games, and Learning. The Mit Press, 21-40. https://doi.org/10.1162/dmal.9780262693646.021

[34] Kenny, R. F., \& McDaniel, R. (2011). The role teachers' expectations and value assessments of video games play in their adopting and integrating them into their classrooms. British Journal of Educational Technology, 42(2), 197-213. https://doi.org/10.1111/j.1467-

\section{$\underline{\text { 8535.2009.01007.x }}$}

[35] Gómez-Carrasco, C. J., Monteagudo-Fernández, J., Moreno-Vera, J. R., \& Sainz-Gómez, M. (2020). Evaluation of a gamification and flippedclassroom program used in teacher training: Perception of learning and outcome. PLoS ONE, $15(7 \quad$ July $), \quad 1-19$. https://doi.org/10.1371/journal.pone.0236083

[36] Kargas, Loumos, \& Varoutas. (2019). Using Different Ways of 3D Reconstruction of Historical Cities for Gaming Purposes: The Case Study of Nafplio. Heritage, 2(3), 1799-1811. https://doi.org/10.3390/heritage2030110 